\title{
The Impact of International Trade on Economic Growth in South Africa: An Econometrics Analysis
}

\author{
Seipati Mogoe \\ Department of Economics, Faculty of and Administration, \\ North-West University (Mafikeng Campus), South Africa \\ Email: seipatimogoe@yahoo.com \\ Itumeleng Pleasure Mongale (PhD) \\ Department of Economics, Faculty of and Administration, \\ North-West University (Mafikeng Campus), South Africa \\ Email: itumeleng.mongale@nwu.ac.za
}

\section{Doi:10.5901/mjss.2014.v5n14p60}

\begin{abstract}
International trade is one of the leading discussions taken not only in South Africa but worldwide on daily basis. The purpose of this study is to examine the impact of foreign trade on economic growth in South Africa. The findings of this study will determine the effects of international trade on economic growth to the policymakers. The study follows the cointegrated vector autoregression approach which contains the following steps: Augmented Dickey-Fuller and Phillips-Perron to test for stationarity. The model is also taken through the Johansen cointegration test and Vector error correction model. The findings of the stationarity tests indicate that all the variables have a unit root problem. The cointegration model emphasizes the long run equilibrium relationship between dependent and independent variables. The empirical results of the Johansen cointegration test reject the null hypothesis of no cointegration and suggest the presence of a long term economic relationship among all the variables. Empirical investigation reveals that inflation rate, export and exchange rates are positively related to GDP whilst import is negatively related to GDP. The conclusion drawn from this work is that there is a correlation amongst GDP and its regressors. This study recommends that the policymakers should improve and strengthen the competiveness of export sector with the aim of striving for a balance with the import sector.
\end{abstract}

Keywords: Economic growth; Foreign trade; Cointegrated Vector Autoregression; South Africa

\section{Introduction}

International trade is one of the leading discussions taking place not only in South Africa but all over the world. The major concern is always about the level of economic growth. According to Qaiser et al (2009) a trade theory indicates that there is generally a positive association among openness, export to growth domestic product (GDP) ratio, investment to GDP ratio and inflation. Kehinde et al., (2012) asserts that trade can promote growth from the supply side, but if the balances of payment cost reduce the availability of imported inputs which enter the product of exports, thus forcing exporters to use expensive imports of double quality. South Africa's economic growth performance has strengthened sustainability since the end of apartheid in 1994. Estimations of potential output growth based on alternative methodologies were conducted, including a standard production function approach. It suggests that during 1995-2003 the rate of potential output growth increased to $3 \%$. The measure of potential output is based on historical rates of factor utilization and total factor productivity (TFP), rather than on full employment. It includes the effects of structural and institutional rigidities that may have impeded growth in the past but not necessarily in the future. The actual rate of real GDP growth also rose to nearly 3,5 from $0.25 \%$ during $1980-94$, largely reflecting a turnaround in TFP growth as the combined growth contribution of labour and capital accumulation stayed roughly unchanged (Arora, 2003).

However, over the past decade South Africa's exports have underperformed. Export growth in real terms has stagnated and the exporters have made only limited inroads into global markets. Be it in minerals, non-minerals or services, South Africa's exports have lagged behind those of peers and not lived up to their potential. That been the case, 
the National Development Plan ${ }^{1}$ is targeting export volume growth of $6 \%$ a year to achieve an annual increase in real GDP of about 5.5\% and to help generate 11 million new jobs by 2030. Despite successes in some subsectors, South Africa will need to greatly improve its export performance to meet these targets (Purfield et al., 2014). The purpose of this study is to investigate the impact of foreign trade on economic growth in South Africa. The significance of trade is vital to any modern economy because it is very crucial to the competitiveness of the economy. Although several studies like Kehinde et al., (2012), Eravwoke and Imide, (2013), etc. have paid attention to trade and economic growth, to our knowledge very few have done an econometric analysis of the impact of international trade on economic growth in South Africa. Besides contribution to existing literature this study will also help policymakers to improve policies on trade in order to expose more of the local products to international competitions.

The main aim of this study is to investigate international trade and its influence on economic growth. The following objectives will used to reach the main aim:

* To identify relevant variables which play a role on international trade and economic growth in South Africa.

* To determine whether international trade and economic growth are correlated in a long run or a short run.

* To determine if international trade affect economic growth of South Africa positively or negatively.

The above objectives will be attained by the use of CVAR framework. The organisation of this study is as follows; Section 2 discuses the literature review, where previous studies that focused on international trade and economic growth and other related topics are discussed. The methodology that is undertaken to perform an econometric analysis of the study is presented in section 3. This section consists of the presentation of the econometric models, variables and data description. Section 4 presents the empirical results. It is mainly the presentation of the economic and statistical outputs which are computed with E-Views 7. Section 5 presents the findings and the conclusion of the investigation.

\section{Literature Review}

Awe (2013) maintains that economic growth is a process whereby the real per capita income for a country increases over a long period of time. Thus, growth occurs when an economy's productive capacity increases which in turn is used to produce more goods and services. It is in view of this that foreign direct investment (FDI) has been seen as being potent for growth. One of the major dynamic benefits of trade is that export markets widen the total market for a country's producers. If production is subject to increasing returns, export growth becomes a continual source of productivity growth. There is also a close connection between increasing returns and the accumulation of capital. For a small country with no trade, there is very little scope for large scale investment in advanced capital equipment; specialisation is limited by the extent of the market. But if a poor and smaller country can trade, there is some prospect of industrialisation and of dispensing with traditional methods of production. It is worth remembering that at least 60 countries in the world and classified as developing, and 31 in Africa, have populations of less than 15 million. Without export markets, the production of many goods would not be economically viable in this continent (Thirlwa, 2000).

Since endogenous-growth models are often thought to have provided the missing theoretical link between trade openness and long-run growth, it is useful to spend a moment on why such models in fact provide an ambiguous answer. As emphasized by Grossman and Helpman (1991), the general answer to the question: "Does trade promote innovation in a small open economy?" is: "It depends." In particular, the answer depends on whether the forces of comparative advantage push the economy's resources in the direction of activities that generate long run growth (via externalities in research and development, expanding product variety, upgrading product quality, and so on) or divert them from such activities. Feenstra (1990), Matsuyama (1992), etc. have worked out examples where a country that is behind in technological development can be driven by trade to specialize in traditional goods and experience a reduction in its longrun rate of growth. Such models are in fact formalisations of some very old arguments about infant industries and about the need for temporary protection to catch up with more advanced countries (Rodrigues et al, 2001).

On the other hand Omoju and Adensaya (2012) established a significant impact of trade openness on level of per capita income. They point out that trade opportunities in an economy has the ability to enhance growth through greater capital stock, stock of education and higher total factor productivity. However, they are also quick to warn against drawing inferences for trade policies based on their results as it brings different factors into play. To take this matter a little further, Cooper (2001) addressed the influence of foreign trade and investment on growth via inequality and distribution of income in developing countries and pointed out that the survey of theory and empirical evidence are rather inconclusive. There are no compelling theoretical reasons to believe, in general, that trade promotes growth and empirical works

\footnotetext{
1 In 2012/2013, African National Congress and South African government adopted the National Development Plan as its launch pad and blueprint for a future economic and socioeconomic development strategy for the country (Zarenda, 2013).
} 
supporting a connection at country level has been heavily criticized on methodological grounds. Cooper lastly maintains that it would be difficult to believe that trade liberalization has not contributed significantly to the growth of the world economy in the second half of the 20th century. The conclusion is that that trade was a product of economic growth; and that the world economy would have grown as rapidly as it did even if trade barriers are as high as they were in the 1950s implying that other factors aside trade also promotes growth. Based on these points raised by several authors, this study intends to study the impact of foreign trade on economic growth in South Africa.

\section{Methodology}

The econometric analysis is performed by using a quarterly time series data from 1990Q1-2013Q2. The data is sourced from the South African Reserve Bank (SARB) and Organisation of Economic Co-operation development (OECD). The study employs a Cointegrated Vector Autoregression (CVAR) approach which covers the stationarity tests, the Johansen cointegration tests and the Vector error correction model (VECM). This study tries to build an econometric model which will be able to provide a better understanding of the relationship between economic growth and international trade in the South African economy. Erhieyovwe and Onokero (2013)'s model will be used as the basis for the formulation of the model of this study. Their model is made up of three variables; namely GDP as an independent variable and Export and Exchange rate as regressors. We use the same variables and in addition, more variables such as Import and Inflation rate are included as other determinants of foreign trade in the South African economy. The study estimates the growth model which can be expressed in its functional forms as follows:

$G D P=f(E X C R A T, E X P T, I M P T, I N F)$

where

GDP $=$ Gross domestic product

EXCRAT = Exchange rate

EXPT= Export

IMPT = Import

INF = Inflation Rate

The above equation can be expressed in a linear function as follows:

$G D P=a_{0}+\beta_{1} E X C R A T+\beta_{2} E X P T+\beta_{3} I M P T+\beta_{4} I N F+\mu \mathrm{t} 3.2$

where

$\mu_{=}$stochastic or random error term (which means properties of zero mean and non-serial correlation).

$\beta_{1}-\beta_{4}=$ Coefficients of associated variables

$a_{0}=$ constant interception

\section{Results and Interpretation}

\subsection{Unit root}

The following section presents the results of unit root tests of Augmented Dickey-Fuller (ADF) and Phillips-Perron (PP). There is a need to examine the stationarity of the variables under consideration in order to avoid having spurious results and to determine the integration properties of all the variables understudy. Only the Trends and Intercept in the model is tested to confirm stationarity. Specific lag length is used so that serial correlation is removed from the error term. The unit root test results are presented on Tables 1 and 2. The ADF test results presented in Table 1 indicate that our variables are nonstationary at levels. They are I(0), meaning that they are nonstationary at levels and they only become I (1) at first differences. The first variable that was tested was GDP which is the dependent variable, at the first form level it was constant, and the problem was it was less negative on the ADF test than the $t$ critical values at $5 \%$. This indicates that the ADF reject the null hypothesis of a unit root at level $\mathrm{I}(0)$. The variable became stationary at first difference. All the variables were nonstationary at level, but became stationary at first difference. 
Table 1: Unit Root Results (ADF test)

\begin{tabular}{|c|c|c|c|c|c|c|c|}
\hline & Model & ADF tests at level & Lag length & First difference & ADF test & Lag length & Order of integration \\
\hline GDP & Trends \& intercepts & $\begin{array}{l}(-2.734259) \\
-3.459397^{\star *}\end{array}$ & 1 & $\Delta \mathrm{GDP}$ & \begin{tabular}{|l}
$(-4.225398)$ \\
$-3.459397^{\star \star}$
\end{tabular} & 0 & $\mathrm{I}(1)$ \\
\hline IMP & Trends \& intercepts & $\begin{array}{c}-2.970382) \\
-3.459397^{\star *}\end{array}$ & 1 & $\Delta \mathrm{MPP}$ & \begin{tabular}{|c|}
$(-7.015095)$ \\
$-3.459397^{\star *}$
\end{tabular} & 0 & $\mathrm{I}(1)$ \\
\hline EXP & Trends \& intercepts & $\begin{array}{c}-1.155557) \\
-3.458856^{\star *}\end{array}$ & 0 & $\Delta \mathrm{EXP}$ & \begin{tabular}{|c|}
$(-8.157154)$ \\
$-3.459397^{\star *}$
\end{tabular} & 0 & $\mathrm{I}(1)$ \\
\hline EXCRAT & Trends \& intercepts & $\begin{array}{l}(-2.252225) \\
-3.459397^{\star \star}\end{array}$ & 1 & $\triangle \mathrm{EXCH}$ & $\begin{array}{l}(-8.147262) \\
-3.459397^{\star *}\end{array}$ & 0 & $\mathrm{I}(1)$ \\
\hline INF & Trends \& intercepts & $\begin{array}{c}(-0.031447) \\
-3.459397^{\star *}\end{array}$ & 0 & $\Delta \mathrm{INF}$ & $\begin{array}{l}(-12,07154) \\
-3.459397^{* *}\end{array}$ & 0 & $\mathrm{I}(1)$ \\
\hline
\end{tabular}

${ }^{\star \star \star} 0.01,{ }^{\star *} 0.05,{ }^{\star} 0.10$ significant level

NOTE: I(1) Indicates unit root at first difference being stationary

$\mathrm{I}(0)$ indicates unit root in level being stationary

$\Delta$ indicates changes in first difference

** indicates critical value at $5 \%$ significance level

Table 2 shows the results of PP test which was performed to verify the unit root tests results performed by the ADF tests.

Table 2: Unit Root Results (PP test)

\begin{tabular}{|c|c|c|c|c|c|c|}
\hline Model & PP test & Band width & First difference & PP test & Band width & Order of integration \\
\hline GDP & Trends \& intercepts & $\begin{array}{c}-2.728751) \\
-3.458856^{\star \star}\end{array}$ & 5 & $\begin{array}{l}(-4.202127) \\
-3.459397^{\star \star}\end{array}$ & 4 & I(1) \\
\hline IMP & Trends \& intercepts & $\begin{array}{c}-2.473299) \\
-3.458865^{\star \star}\end{array}$ & 1 & $\begin{array}{l}(-6.89080) \\
-3.459397\end{array}$ & 4 & I(1) \\
\hline EXP & Trends \& intercepts & $\begin{array}{c}(-1.1555572) \\
-3.458856^{\star *}\end{array}$ & 0 & $\begin{array}{l}(-8.147800) \\
-3.459397^{\star \star}\end{array}$ & 2 & I(1) \\
\hline EXCRAT & Trends \& intercepts & $\begin{array}{l}(-1.839999) \\
-3.458856^{* *}\end{array}$ & 2 & $\begin{array}{l}(-8.165197) \\
-3.459397^{\star *}\end{array}$ & 1 & I(1) \\
\hline INF & Trends \& intercepts & $\begin{array}{c}(-0.196312) \\
-3.458856^{\star \star}\end{array}$ & 13 & $\begin{array}{c}(-12.14429) \\
-3.459397^{* *}\end{array}$ & 8 & I(1) \\
\hline
\end{tabular}

${ }^{\star * \star} 0.01,{ }^{* \star} 0.05,{ }^{*} 0.10$ significant level

NOTE: I(1) Indicates unit root at first difference being stationary

$I(0)$ indicates unit root in level being stationary

$\Delta$ indicates changes in first difference

** indicates critical value at $5 \%$ significance level

The results of PP unit root test confirm that GDP is not stationary at level, that is, it is I(0) . All the variables including inflation were non-stationary at level, but became stationary at first difference I(1).

The results of the two tests indicate that all the series are found to be nonstationary; however the $1^{\text {st }}$ differences of these series lead to stationarity. The integration of GDP, exchange rate, exports, import and inflation rate is of order one i.e. I(1). Based on these results, we continued to test whether our five series are cointegrated over the sample period of our study.

\subsection{Johannes cointegration}

The Johannes cointegration test is conducted with the purpose of examining the presence or absence of cointegration among the variables. The presence cointegration will then be an indication or confirmation of a long run economic relationship among the variables. 
Table 3: Unrestricted Cointegration Rank Test (Trace)

\begin{tabular}{ccccc}
\hline \hline $\begin{array}{c}\text { Hypothesized } \\
\text { No. of CE }(\mathrm{s})\end{array}$ & Eigenvalue & $\begin{array}{c}\text { Trace } \\
\text { Statistic }\end{array}$ & $\begin{array}{c}0.05 \\
\text { Critical Value }\end{array}$ & Prob.*** \\
\hline \hline None * & 0.375144 & 93.85690 & 69.81889 & 0.0002 \\
At most 1 * & 0.285801 & 51.06561 & 47.85613 & 0.0242 \\
At most 2 & 0.117625 & 20.43564 & 29.79707 & 0.3938 \\
At most 3 & 0.066325 & 9.048059 & 15.49471 & 0.3610 \\
At most 4 & 0.030333 & 2.803018 & 3.841466 & 0.0941 \\
\hline \hline
\end{tabular}

Trace test indicates 2 cointegrating eqn(s) at the 0.05 level

* denotes rejection of the hypothesis at the 0.05 level

**MacKinnon-Haug-Michelis (1999) p-values

Table 4: Unrestricted Cointegration Rank Test (Maximum Eigenvalue)

\begin{tabular}{ccccc}
\hline \hline $\begin{array}{c}\text { Hypothesized } \\
\text { No. of CE }(\mathrm{s})\end{array}$ & Eigenvalue & $\begin{array}{c}\text { Max-Eigen } \\
\text { Statistic }\end{array}$ & $\begin{array}{c}0.05 \\
\text { Critical Value }\end{array}$ & Prob.** \\
\hline \hline None & 0.375144 & 42.79129 & 33.87687 & 0.0034 \\
At most 1 & 0.285801 & 30.62997 & 27.58434 & 0.0197 \\
At most 2 & 0.117625 & 11.38758 & 21.13162 & 0.6086 \\
At most 3 & 0.066325 & 6.245041 & 14.26460 & 0.5820 \\
At most 4 & 0.030333 & 2.803018 & 3.841466 & 0.0941 \\
\hline \hline
\end{tabular}

Max-eigenvalue test indicates 2 cointegrating eqn(s) at the 0.05 level

* denotes rejection of the hypothesis at the 0.05 level

**MacKinnon-Haug-Michelis (1999) p-values

Both the trace and the maximum eigenvalue tests results in Tables 3 and 4 respectively reject the null hypothesis of no cointegration. They indicate the presence of two cointegrating equations at $5 \%$ level of significance. The implication is that there is a long run relationship between the dependent variable GDP and its regressors. According to Gujarati et al (2009), as the critical values increase, the $p$-values decrease. Given that the p-values in Table 3 are closer to zero the null hypotheses is rejected with increasing confidence. Since all the variables were found to be stationary and cointergrated, the study can now perform the VECM not VAR.

\subsection{Vector error correction model}

The VECM results indicate that there is correlation between GDP and the four independent variables. The implication is that there is an existence of a short run economic relationship. The Adjusted R- squared of $0.579(58 \%)$ indicates that 0.58 of the model is perfectly fit meaning that the regression is not spurious and the F-statistic revealed the absence of serial autocorrelation. The estimated coefficient value of EC $(-0.004996)$ in Table 4 has a priori (negative) sign which is an indication of the fact that any short-term fluctuations between the independent variables and the dependent variables will give rise to a stable long run relationship between variables (Asari et al. 2011). The prior sign also indicate that our variable is well defined as it observes the usual negative sign of -0.004996 which enables it to adjust to equilibrium position whenever the system is out of equilibrium. The estimated coefficient indicates that about $0.5 \%$ of this disequilibrium is corrected within one quarter. 
Table 4: Summary of the VECM estimation

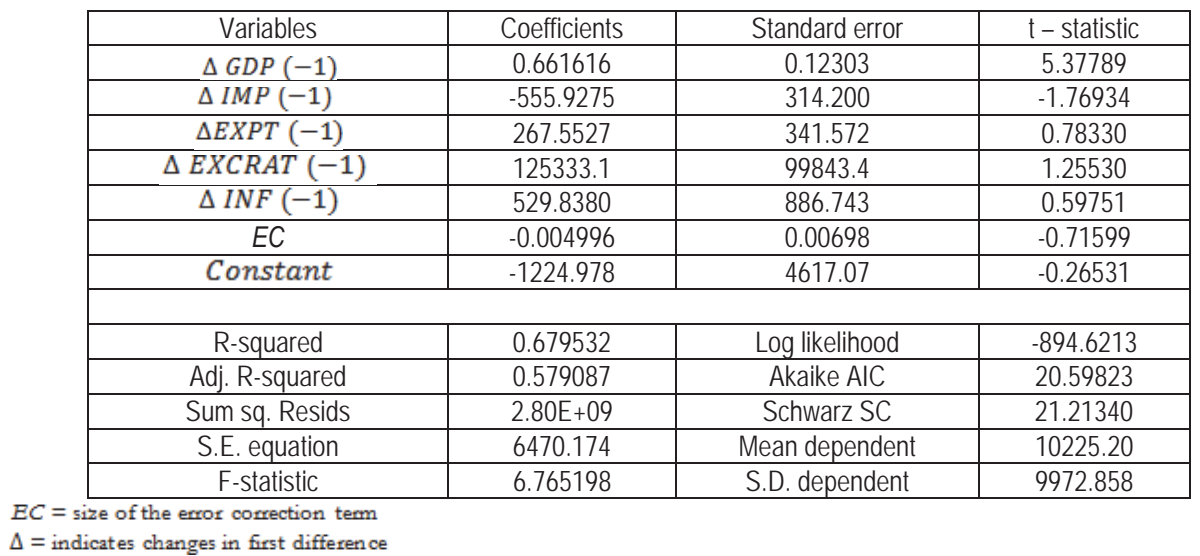

Finally the results estimated on VECM at lag 1, shows that there is a positive relationship between GDP, inflation rate, export and exchange rate. However, import is negatively related to GDP.

\section{Conclusion and Policy Recommendations}

The study analysed the impact of foreign trade on economic growth in South Africa with the aim of addressing three objectives. The first one being to identify relevant variables which play role on international trade and also economic growth after trade has taken place. The second one is to determine whether international trade and GDP are correlated in a long run or a short run. Lastly is to determine if international trade affect economic growth of South Africa positively or negatively.

This paper employs the CVAR model to examine the impact of international trade on economic growth in South Africa. The Erhieyovwe and Onokero (2013)'s model was used as the basis for the formulation of the model of the study. The ADF and PP analytic techniques were performed to test for stationarity. All the variables were not stationary at levels, but they were stationary at first difference. The Johannes Cointegration tests, results indicated that all the variables produced a long run relationship. The implication is that export, import, economic growth, exchange rate and inflation rate have a long run economic relationship as indicated by both the maximum eigenvalue and the trace test statistics which rejected the null hypothesis of no cointegration. The VECM result revealed that the speed of adjustment towards the long run equilibrium is significant, meaning that the dependent variables have a long run relationship with the dependent variables.

The study examined the impact of foreign trade on economic growth in South Africa. The results show that inflation rate, exports and exchange rate are positively related to GDP, while import has a negative influence on GDP. These results are in line with Erhieyovwe and Onokero (2013) who maintained that the level of exports is highly significant for an international trade. Based on our empirical results exports have a potential to create growth and expansion of infrastructure in the South African economy. The negative relationship between GDP and exchange rate is a cause for concern since it has a huge impact on trading. The South African economy growth rate has apparently slowed down in the second quarter of 2013. Given this, the government needs to strengthen, support and encourage the competitiveness of exports by making sure that it maintains a sustainable balance with the imports. A serious attention must be paid to the unstable currency which has a negative impact on economic growth. Therefore there is a need to monitor its performance in relations to the currencies of other developing economies.

\section{References}

Eravwoke, K. E. \& Imide, I. O. (2013). International Trade as an Engine of Growth in Developing Countries: A Case Study of Nigeria. An International Multidisciplinary Journal, Ethiopia 7.

Kehinde, A., Jubril, A., Felix, A. \& Edun, F. (2012). Foreign Trade and Economic Growth in Nigeria: An Empirical Analysis. American Academic \& Scholarly Research Journal, 4.

Arora, V. (2003). Economic growth in post-apartheid in South Africa: A growth accounting. In Michael Nowak \& Luca Antonio Ricci 
(Eds.), Post-Apartheid South Africa: The First Ten Years. Washington, D.C.: International Monetary Fund.

Awe, A.A. (2013). The Impact of Foreign Direct Investment on Economic Growth in Nigeria. Journal of Economics and Sustainable Development, 4(2)

Cooper, R. N. (2001). Growth and Inequality: The role of foreign trade and investment. In B. Pleskovic \& N. Stern (Eds.), Annual World Bank Conference on Development Economics 2001/2002. New York: World Bank and Oxford University Press.

Feenstra, R. C. (1996). Trade and uneven growth. Journal of Development Economics, 49(1), 229-256.

Grossman, G.M., \& Helpman, E. (1991). Innovation and Growth in the Global Economy. Cambridge: The MIT Press.

Javed, Z. H., Mushtaq, A., Saif-ullaha, \& Iqbal, A. (2012). Effects of International Trade On Economic Growth: The Case Study of Pakistan. International Journal of Academic Research in Progressive Education and Development, 1(2).

Matsuyama, K. (1992). Agricultural productivity, comparative advantage, and economic growth. Journal of Economic Theory, 58(2), 317334.

Omoju, O., \& Adesanya, O. (2012). Does trade promote growth in developing countries? Empirical evidence from Nigeria. International Journal of Development and Sustainability, 1(2), 743-753.

Purfield, C. M., Farole, T., \& Im, F. (2014). South Africa Economic Update: Focus on Export Competitiveness South Africa economic update (Vol. 5). Washington, DC: World Bank Group.

Rodríguez, F., \& Rodrik, D. (2001). Trade Policy and Economic Growth: A Skeptic's Guide to the Cross-National Evidence. In B. S. Bernanke \& K. Rogoff (Eds.), NBER Macroeconomics Annual 2000, Volume 15. Cambridge: MIT Press.

Thirlwall, A. P. (2000). Trade, Trade Liberalisation and Economic Growth: Theory and Evidence. Economic Research Papers, 63.

Zarenda, H. (2013). South Africa's National Development Plan and its implications for regional development Tralac Working Paper. Stellenbosch: Tralac. 